Article

\title{
Effects of water on the hydrogenation of acetone over Ni/MgAlO catalysts
}

\author{
Hui Chen, Jie Zhao, Shaozhong Li, Jun Xu, Jianyi Shen* \\ Key Laboratory of Mesoscopic Chemistry of MOE, School of Chemistry and Chemical Engineering, Nanjing University, Nanjing 210093, Jiangsu, China
}

\section{A R T I C L E I N F O}

Article history:

Received 15 August 2014

Accepted 29 September 2014

Published 20 March 2015

\section{Keywords:}

Nickel

Supported catalyst

Hydrogenation of acetone

Effect of water

Microcalorimetric adsorption

Fourier transform infrared

spectroscopy

\begin{abstract}
A B S T R A C T
The effect of water on the hydrogenation of acetone to isopropanol (IPA) on the Ni/MgAlO catalyst was studied. It was found that small amount of water added in the acetone promoted the conversion of acetone to IPA, while more $\mathrm{H}_{2} \mathrm{O}$ added ( $>5 \%$ ) significantly decreased the conversion of acetone. Microcalorimetric adsorption results showed that the presence of small amount of pre-adsorbed water ( $4 \%$ coverage) enhanced the adsorption of acetone while inhibited the adsorption of IPA on $\mathrm{Ni}$, which might be the important reasons for the promotion effect of some water on the hydrogenation of acetone to IPA. On the other hand, the heats for the adsorption of $\mathrm{H}_{2}$, acetone and IPA on the $\mathrm{Ni} / \mathrm{MgAlO}$ were significantly decreased when more water was pre-adsorbed, which might explain the inhibition effect of more water on the hydrogenation of acetone. The results of infrared spectroscopy revealed that the presence of water suppressed the dehydrogenation of adsorbed IPA to acetone and the formation of enolate and mesityl oxide species from adsorbed acetone, which might be the other reasons for the positive effect of water on the hydrogenation of acetone to IPA.
\end{abstract}

(C) 2015, Dalian Institute of Chemical Physics, Chinese Academy of Sciences. Published by Elsevier B.V. All rights reserved.

\section{Introduction}

The heterogeneous catalytic hydrogenation of aldehydes and ketones to the corresponding alcohols is of great importance in the manufacture of fine chemicals. Many such hydrogenation reactions are performed in solvents. It is therefore important to choose an appropriate solvent for a given reaction [1-4]. Water is considered to be a green solvent because it is abundant, cheap, safe, and environmentally benign $[5,6]$. In addition, many aldehydes and ketones are easily dissolved in water. However, it has been claimed that water influences the activities and selectivities of hydrogenation reactions [7-14]. Akpa et al. [11] studied the effect of a mixed solvent (water/isopropanol (IPA)) on the liquid-phase hydrogenation of 2-butanone to 2-butanol experimentally and using theoretical calculations. They found that the hydrogenation rate of 2-butanone increased with increasing water fraction in the water/IPA mixture. The theoretical calculations showed that water significantly lowered the reaction activation energy and even changed the hydrogennation mechanism. Vaidya et al. [12] reported that the addition of water led to a marked increase in activity in the hydrogenation of $n$-valeraldehyde to $n$-amyl alcohol over a $5 \% \mathrm{Ru} / \mathrm{Al}_{2} \mathrm{O}_{3}$ catalyst. Masson et al. [10] studied the hydrogenation of acetophenone over Raney $\mathrm{Ni}$ and found that the presence of water decreased adsorption of the aromatic rings of acetophenone and 1-phenylethanol, resulting in significantly improved selectivity for the desired product, 1-phenylethanol. Many factors such as the polarity, dielectric

\footnotetext{
* Corresponding author. Tel/Fax: +86-25-83594305; E-mail: jyshen@nju.edu.cn

This work was supported by the National Natural Science Foundation of China (21273105), the Natural Science Foundation of Jiangsu Province, China (BK20140596), and the National High Technology Development Program of China (863 Program, 2013AA031703). DOI: 10.1016/S1872-2067(14)60240-0 | http://www.sciencedirect.com/science/journal/18722067 | Chin. J. Catal., Vol. 36, No. 3, March 2015
} 
constant, solubilities of gas reactants (e.g., $\mathrm{H}_{2}$ ), mass transfer, interactions among reacting species (e.g., hydrogen bonding), and competitive adsorption have been investigated to explain solvent effects on catalytic hydrogenation reactions [1-3,8-14]. However, much more work is needed to understand solvent effects better. The adsorption, interactions, and surface reactions of solvent molecules with the reactant and product molecules are key factors in heterogeneous catalytic reactions. In this work, we studied the effects of water on the hydrogenation of acetone on a $\mathrm{Ni} / \mathrm{MgAlO}$ catalyst, in which the MgAlO support was a complex oxide of $\mathrm{MgO}$ and $\mathrm{Al}_{2} \mathrm{O}_{3}$.

Studies of the adsorption of acetone on clean surfaces are well documented in the literature. Two configurations, i.e., end-on $\eta^{1}(\mathrm{O})$ and side-on $\eta^{2}(\mathrm{C}, 0)$ modes, have been identified for the adsorption of acetone on metal surfaces [15-17]. Enol and/or enolate species, the isomers of ketonic acetone, were also found on the surfaces of metals and metal oxides [18-22]. Transition-metal enolate complexes have been identified as the key intermediates in a number of $\mathrm{C}$-C-bond-forming reactions. The adsorption of IPA on clean surfaces has also been well documented [23-26]. The IPA adsorption states on metal surfaces are temperature dependent [23]. Non-dissociative adsorption of IPA was observed on the $\mathrm{Ni}(111)$ surface at $110 \mathrm{~K}$. When the temperature was increased to $200 \mathrm{~K}$, dissociative adsorption of IPA occurred, with formation of isopropoxide surface species, which were stable up to $320 \mathrm{~K}$. At higher temperatures, the $\alpha-\mathrm{C}-\mathrm{H}$ bond breaks, with simultaneous formation of acetone. However, to the best of our knowledge, there are few reports on the effects of pre-adsorbed water on the adsorption of acetone and IPA. In this work, microcalorimetric adsorption and Fourier-transform infrared (FT-IR) spectroscopy were used to study the adsorption of water on a $\mathrm{Ni} / \mathrm{MgAlO}$ catalyst and its effect on the adsorption of $\mathrm{H}_{2}$, acetone, and IPA. This will enable a better understanding of the effects of water on the hydrogenation of aldehydes and ketones.

\section{Experimental}

\subsection{Catalyst preparation}

A $60 \mathrm{wt} \% \mathrm{Ni} / \mathrm{MgAlO}$ catalyst $\left(\mathrm{MgO} / \mathrm{Al}_{2} \mathrm{O}_{3}=3, w / w\right)$ was prepared using the coprecipitation method described in the literature [27]. An aqueous solution (100 mL) containing $\mathrm{Ni}$, $\mathrm{Mg}$, and $\mathrm{Al}$ nitrates and an aqueous solution (100 mL) of $\mathrm{Na}_{2} \mathrm{CO}_{3}$ were simultaneously added to a beaker containing distilled water $(200 \mathrm{~mL})$ at $353 \mathrm{~K}$ under vigorous stirring. The formed precipitate was removed by filtration and washed thoroughly with deionized water. The filter cake was dispersed in $n$-butanol $(200 \mathrm{~mL})$, heated to $353 \mathrm{~K}$, and held at that temperature for $12 \mathrm{~h}$, during which the water and $n$-butanol evaporated. The obtained powder was dried in an oven at $393 \mathrm{~K}$ overnight. The catalyst was reduced in a reactor in flowing $\mathrm{H}_{2}$ at $723 \mathrm{~K}$ for $2 \mathrm{~h}$ before the reaction. The catalyst was denoted by $\mathrm{Ni} / \mathrm{MgAlO}$. The MgAlO support $\left(\mathrm{MgO} / \mathrm{Al}_{2} \mathrm{O}_{3}=3, w / w\right)$ was prepared using the same method.

\subsection{Catalyst characterization}

The chemical composition of the catalyst was determined using inductively coupled plasma atomic emission spectroscopy (J-A1100, Jarrell-Ash Co., USA). The mass percentages of $\mathrm{Ni}, \mathrm{MgO}$, and $\mathrm{Al}_{2} \mathrm{O}_{3}$ in the reduced $\mathrm{Ni} / \mathrm{MgAlO}$ catalyst were $64 \%$, $26.5 \%$, and $9.5 \%$, respectively.

$\mathrm{N}_{2}$ adsorption-desorption isotherms were measured at $77 \mathrm{~K}$ using a Micromeritics Gemini V 2380 autosorption analyzer. The samples were degassed at $573 \mathrm{~K}$ in a $\mathrm{N}_{2}$ flow for $2 \mathrm{~h}$ before the measurements. The specific surface areas were calculated using the BET method, and the pore size distributions were obtained by the BJH method, using the desorption branch data.

X-ray diffraction (XRD) patterns were obtained in an ambient atmosphere, using an X-ray diffractometer (Shimadzu XRD-6000) with $\mathrm{Cu} K_{\alpha}$ radiation $(\lambda=1.5408 \AA$ ) generated at 40 $\mathrm{kV}$ and $30 \mathrm{~mA}$. Diffraction intensities were recorded from $10^{\circ}$ to $80^{\circ}$ at a rate of $7^{\circ} / \mathrm{min}$.

Adsorptions of $\mathrm{H}_{2}$ and $\mathrm{O}_{2}$ were performed using a laboratory-made volumetric adsorption system at room temperature and $673 \mathrm{~K}$, respectively. The detailed experimental information was given in our previous work [27-29]. The reduction degree, dispersion, active surface area, and particle size of metallic $\mathrm{Ni}$ in the $\mathrm{Ni} / \mathrm{MgAlO}$ catalyst used in this work were estimated to be $76.9 \%, 27.6 \%, 75.6 \mathrm{~m}^{2} / \mathrm{g}_{\text {cat }}$, and $3.6 \mathrm{~nm}$, respectively.

Microcalorimetric adsorptions of $\mathrm{H}_{2}$, acetone, and IPA were performed using a Tian-Calvet heat-flux apparatus. A C-80 calorimeter (Setaram, France) was connected to a volumetric system equipped with a Baratron capacitance manometer (USA) for precision pressure measurements $\left( \pm 0.5 \times 10^{-4}\right.$ Torr) and gas handling. Prior to the microcalorimetric adsorption, the catalyst was typically reduced in $\mathrm{H}_{2}$ at $723 \mathrm{~K}$ for $2 \mathrm{~h}$, followed by evacuation at the same temperature for $1 \mathrm{~h}$. In the case of the microcalorimetric adsorptions of acetone, $\mathrm{H}_{2}$, and IPA on the $\mathrm{Ni} / \mathrm{MgAlO}$ catalyst with pre-adsorbed water, doses of water vapor were first injected sequentially into the adsorption cell until the desired pre-adsorption coverage was achieved, calculated according to the saturation coverage of water on the catalyst.

The FT-IR spectra of adsorbed acetone and IPA were recorded using a EUNIOX55 FTIR spectrometer (mercury cadmium telluride detector) in the range $4000-1000 \mathrm{~cm}^{-1}$, with a resolution of $2 \mathrm{~cm}^{-1}$. A self-supporting wafer (15-20 mg) was reduced in situ in the IR cell at $723 \mathrm{~K}$ in $\mathrm{H}_{2}$ for $2 \mathrm{~h}$ and the cell was evacuated at the same temperature for $1 \mathrm{~h}$. The IR cell was cooled, and then acetone or IPA was introduced into the cell at a given temperature. After evacuation, the FT-IR spectra were recorded at room temperature.

\subsection{Catalytic tests}

The hydrogenation reactions were performed in a vertical stainless-steel trickle-bed reactor with an inner diameter of 10 $\mathrm{mm}$. The hydrogenation of acetone is strongly exothermic, therefore the $\mathrm{Ni} / \mathrm{MgAlO}$ catalyst was diluted with the MgAlO support at a mass ratio of $\mathrm{Ni} / \mathrm{MgAlO}: \mathrm{MgAlO}=1: 10$ to form a 
composite catalyst ( $\mathrm{Ni} / \mathrm{MgAlO}-\mathrm{MgAlO}$ ). This composite catalyst was pelletized, crushed, and sieved to 40-60 mesh. The composite catalyst (about $0.1 \mathrm{~g}$ ) was loaded in the middle of the reactor, and the remaining reactor volumes at the both ends of catalyst bed were filled with silica particles of the same mesh. The catalyst was reduced in flowing $\mathrm{H}_{2}$ at $723 \mathrm{~K}$ for $2 \mathrm{~h}$ and cooled to the reaction temperature. A feed of pure or water-containing acetone was then delivered to the reactor using a 2ZB-1L10 dual-plunger infinitesimal quality metering pump, and flowed downward with $\mathrm{H}_{2}\left(\mathrm{H}_{2} /\right.$ acetone $\left.=4, \mathrm{~mol} / \mathrm{mol}\right)$ through the packed catalyst. Acetone hydrogenation was performed at $333 \mathrm{~K}$ and $4 \mathrm{MPa}$ with an acetone weight hourly space velocity (WHSV) of $96 \mathrm{~h}^{-1}$. The products were collected and analyzed using a gas chromatograph (Agilent 7820A) equipped with an HP-5 capillary column (353 K) and a flame-ionization detector ( $523 \mathrm{~K})$. The activity and selectivity of the reaction were calculated based on the gas chromatography results.

\section{Results and discussion}

\subsection{Effects of water on hydrogenation of acetone}

Figure 1 shows the results for the hydrogenation of pure and water-containing acetone at $333 \mathrm{~K}, 4 \mathrm{MPa}$, and an acetone WHSV of $96 \mathrm{~h}^{-1}$ on the composite catalyst (Ni/MgAlO-MgAlO). The reaction was performed at a relatively high pressure and WHSV to minimize the limitations of gas-liquid and liquid-liquid mass transfers [30,31]. IPA was the only product analyzed. The acetone conversion was about $83 \%$ for the hydrogenation of pure acetone under the reaction conditions. The addition of $1 \%$ and $2 \%$ water to the acetone increased the conversions of acetone to $92 \%$ and $93 \%$, respectively, but addition of more water decreased the acetone conversion; for example, only $37 \%$ acetone was converted when the feed contained $40 \%$ water. These results are in good agreement with those reported in the literature, i.e., that the addition of a small amount of water $(1 \%-2 \%)$ accelerated acetone hydrogenation [11-14]. However, the addition of more water had the opposite effect.

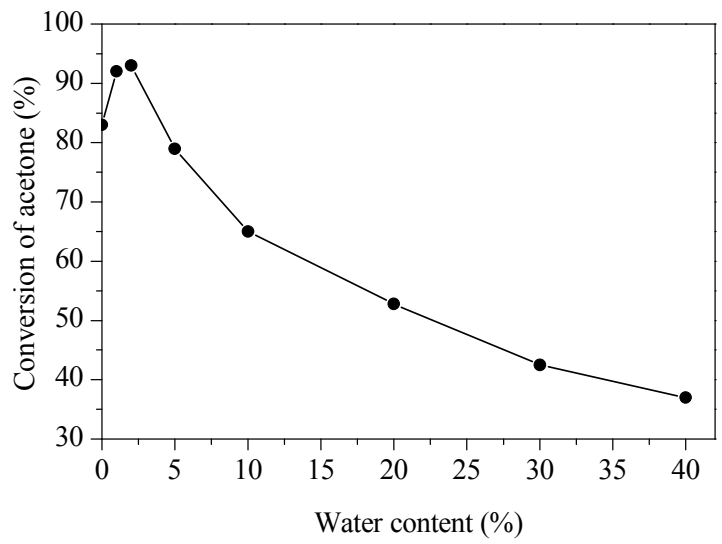

Fig. 1. Conversion of acetone in hydrogenation of acetone containing different amounts of water on composite $\mathrm{Ni}$ catalyst $(\mathrm{Ni} / \mathrm{MgAlO}$ and MgAlO at weight ratio of $1: 10)$. Reaction conditions: $T=333 \mathrm{~K}, P=4$ $\mathrm{MPa}, \mathrm{WHSV}_{\text {acetone }}=96 \mathrm{~h}^{-1}, \mathrm{H}_{2} /$ acetone molar ratio $=4$.

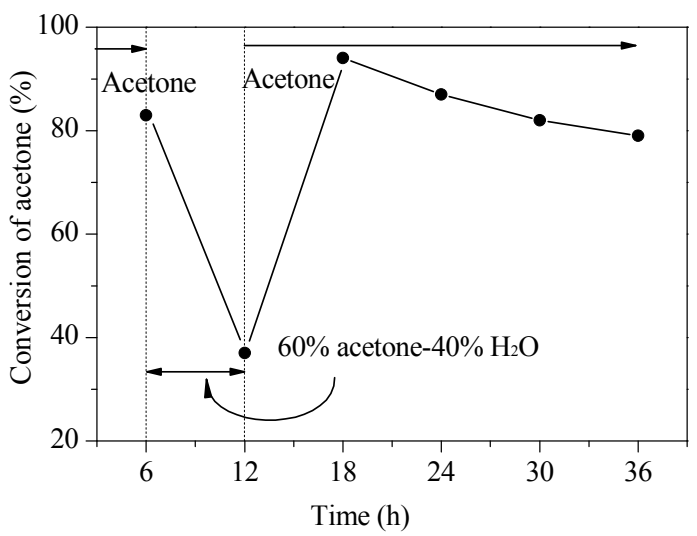

Fig. 2. Plot of acetone conversion versus reaction time for hydrogenation of acetone with alternating feeds of pure acetone and $60 \%$ acetone-40\% water on composite $\mathrm{Ni}$ catalyst $(\mathrm{Ni} / \mathrm{MgAlO}$ and $\mathrm{MgAlO}$ at a weight ratio of 1:10). Reaction conditions: $T=333 \mathrm{~K}, P=4 \mathrm{MPa}$, $\mathrm{WHSV}_{\text {acetone }}=96 \mathrm{~h}^{-1}, \mathrm{H}_{2}$ /acetone molar ratio $=4$.

To determine whether the effects of water on acetone hydrogenation were reversible, pure acetone and an aqueous solution of acetone $(60 \%)$ were fed alternately into the reactor. The results are shown in Fig. 2. Pure acetone was first fed for 6 $\mathrm{h}$; the acetone conversion was $83 \%$ after $6 \mathrm{~h}$. The feed was then switched to an aqueous solution of acetone, and the acetone conversion decreased greatly. After $12 \mathrm{~h}$, the acetone conversion had decreased to only $37 \%$ when the solution contained $40 \%$ water. The feed was then switched back to pure acetone, and the acetone conversion increased significantly to $94 \%$ at $18 \mathrm{~h}$. These results clearly show that the presence of water affected the hydrogenation of acetone on the catalyst surface (water could participate in the surface reactions in some way), and affected the textural and structural properties of the catalyst.

\subsection{Effects of water on textural and structural properties of catalyst}

Table 1 summarizes the BET surface areas and pore parameters of the composite catalyst after hydrogenation of acetone in the presence of different amounts of water. The surface area, pore volume, and average pore size were $214 \mathrm{~m}^{2} / \mathrm{g}, 0.81 \mathrm{~mL} / \mathrm{g}$,

Table 1

Textural properties of composite catalyst (Ni/MgAlO-MgAlO) after hydrogenation of acetone containing different amounts of water.

\begin{tabular}{lccc}
\hline $\mathrm{H}_{2} \mathrm{O}$ content (wt\%) & $A_{\mathrm{BET}}\left(\mathrm{m}^{2} / \mathrm{g}\right)$ & $V_{\mathrm{p}}(\mathrm{mL} / \mathrm{g})$ & Pore size $(\mathrm{nm})$ \\
\hline 0 & 214 & 0.81 & 15.1 \\
1 & 210 & 0.71 & 13.4 \\
2 & 203 & 0.71 & 13.9 \\
5 & 104 & 0.38 & 14.4 \\
10 & 97 & 0.43 & 17.8 \\
20 & 99 & 0.41 & 16.8 \\
30 & 97 & 0.41 & 17.6 \\
40 & 108 & 0.45 & 16.8 \\
\hline
\end{tabular}

Note: The composite catalyst was composed of $\mathrm{Ni} / \mathrm{MgAlO}$ and its support MgAlO at the weight ratio of 1:10. Reaction conditions: $T=333 \mathrm{~K}, P$ $=4 \mathrm{MPa}, \mathrm{WHSV}_{\text {acetone }}=96 \mathrm{~h}^{-1}, \mathrm{H}_{2} /$ acetone molar ratio $=4$. 
and $15.1 \mathrm{~nm}$, respectively, for the composite catalyst after hydrogenation of pure acetone. All three parameters decreased slightly for the composite catalyst after hydrogenation of acetone containing $1 \%$ or $2 \%$ water. However, the surface area and pore volume decreased significantly, and the pore size increased significantly, for the composite catalyst after hydrogenation of acetone containing more than $5 \%$ water. Water therefore clearly affected the textural properties of the composite catalyst, especially when the water content was more than $5 \%$.

Figure 3(a) shows the XRD patterns of the composite catalyst after hydrogenation of acetone containing different amounts of water. The amount of $\mathrm{Ni}$ in the composite catalyst was low (about 6\%); therefore, no metallic Ni peaks were observed in the XRD patterns. Two distinct diffraction peaks characteristic of $\mathrm{MgO}$ [27] were detected at $2 \theta=43.3^{\circ}$ and $63.1^{\circ}$ (JCPDS 45-0946) for the composite catalyst after the hydrogenation of acetone containing no more than $2 \%$ water. These MgO peaks disappeared for the composite catalyst after hydrogenation of acetone containing more than $5 \%$ water. New peaks appeared at $2 \theta=11.5^{\circ}, 23.0^{\circ}, 34.7^{\circ}, 39.2^{\circ}, 46.6^{\circ}, 60.4^{\circ}$, and $62^{\circ}$, assigned to $\mathrm{Mg}_{6} \mathrm{Al}_{2}(\mathrm{OH})_{18} \cdot 4.5 \mathrm{H}_{2} \mathrm{O}$ (JCPDS 35-0965), indicating a phase change of the composite catalyst during the hydrogenation of acetone containing significant amounts of water $(>5 \%)$.

An unsupported $\mathrm{Ni} / \mathrm{MgAlO}$ catalyst was also studied for comparison. The XRD patterns of $\mathrm{Ni} / \mathrm{MgAlO}$ after the hydro-

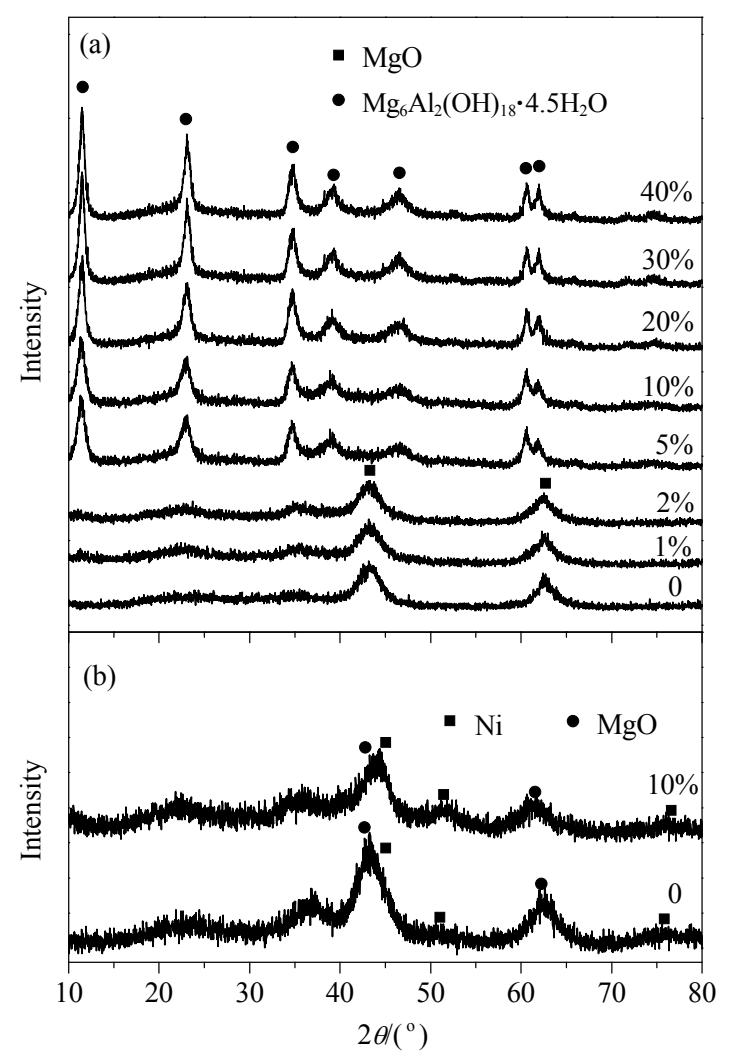

Fig. 3. XRD patterns of composite catalyst (a) composed of Ni/MgAlO and MgAlO at a weight ratio of 1:10, and Ni/MgAlO (b) after hydrogenation of acetone containing different amounts of water. genation of pure acetone and acetone containing 10\% water are shown in Fig. 3(b). Two phases, metallic Ni and MgO, were clearly seen in the two XRD patterns, and no $\mathrm{Mg}_{6} \mathrm{Al}_{2}(\mathrm{OH})_{18} \cdot 4.5 \mathrm{H}_{2} \mathrm{O}$ phase was observed for the $\mathrm{Ni} / \mathrm{MgAlO}$ catalyst after hydrogenation of acetone containing $10 \%$ water. This indicated that the phase change for the composite catalyst during hydrogenation of acetone in the presence of significant amounts of water was probably a phase change of the MgAlO support. The effects of water on the hydrogenation of acetone could therefore mainly arise from the effects of water on surface reactions.

\subsection{Effects of water on adsorptions of $\mathrm{H}_{2}$, acetone, and IPA}

The interactions of molecularly adsorbed water with metal and metal oxide surfaces have been extensively studied and comprehensively summarized in several reviews [32,33]. Water molecules are commonly thought to adsorb on the metal surface via the oxygen atom, and then aggregate via hydrogen bonding to form water multilayers or clusters. On metal oxide surfaces, the water molecules are typically adsorbed at Lewis acid sites via the lone pair of electrons on the oxygen in water [34]. In addition, the adsorbed water molecules can be partially or completely dissociated to $\mathrm{H}, \mathrm{OH}$, and/or $\mathrm{O}$ surface species on the metal and metal oxide surfaces at high temperatures [32,34-36].

Figure 4 shows the microcalorimetric adsorption results for $\mathrm{H}_{2}$ at $308 \mathrm{~K}$ over the $\mathrm{Ni} / \mathrm{MgAlO}$ catalyst with different coverages of pre-adsorbed water. The initial heat was $85 \mathrm{~kJ} / \mathrm{mol}$ for the adsorption of $\mathrm{H}_{2}$ on the clean $\mathrm{Ni} / \mathrm{MgAlO}$ catalyst. The initial heat and coverage decreased continuously for the adsorption of $\mathrm{H}_{2}$ on the $\mathrm{Ni} / \mathrm{MgAlO}$ catalyst with increasing coverage of pre-adsorbed water. It should be noted that at low coverages of pre-adsorbed water $(<10 \%)$, the decreases in the initial heats

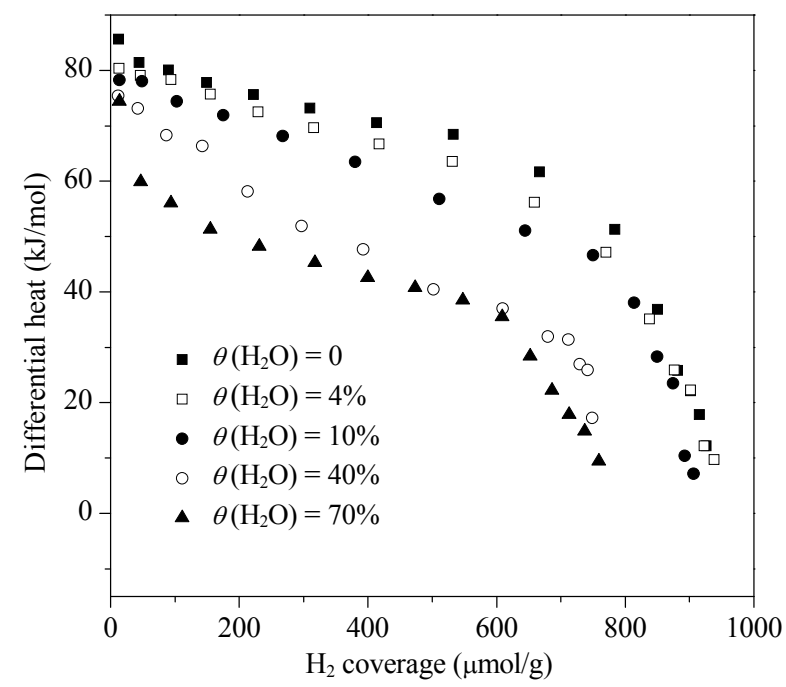

Fig. 4. Plots of differential heat versus coverage for adsorption of $\mathrm{H}_{2}$ at $308 \mathrm{~K}$ over $\mathrm{Ni} / \mathrm{MgAlO}$ with different coverages $(\theta)$ of pre-adsorbed water. The $\mathrm{Ni} / \mathrm{MgAlO}$ was reduced at $723 \mathrm{~K}$ in $\mathrm{H}_{2}$ for $2 \mathrm{~h}$ and then evacuated for $1 \mathrm{~h}$ at $723 \mathrm{~K}$ prior to pre-adsorption of water. The coverage of pre-adsorbed water was achieved by controlling the dosages of water injected, based on the saturation coverage of water. 
and coverages of $\mathrm{H}_{2}$ were not significant, indicating that small amounts of water might be preferentially adsorbed on the support, rather than on the Ni surface. With increasing amount of pre-adsorbed water, more water molecules were adsorbed on the Ni surface, leading to significant decreases in the heats and coverages for the adsorption of $\mathrm{H}_{2}$ on $\mathrm{Ni}$. Water is an electron donor, therefore the pre-adsorbed water might increase the electron density of the surface $\mathrm{Ni}$ and thus weaken the $\mathrm{Ni}-\mathrm{H}$ bonds [37].

Figure 5 shows the microcalorimetric results for adsorption of acetone at $308 \mathrm{~K}$ over the $\mathrm{Ni} / \mathrm{MgAlO}$ catalyst with different coverages by pre-adsorbed water. The initial heats were 68 and $131 \mathrm{~kJ} / \mathrm{mol}$ for the adsorptions of acetone on MgAlO and clean $\mathrm{Ni} / \mathrm{MgAlO}$, respectively, indicating that acetone was adsorbed much more strongly on metallic Ni than on the MgAlO support. The initial heat was slightly higher $(139 \mathrm{~kJ} / \mathrm{mol})$ for the adsorption of acetone on the $\mathrm{Ni} / \mathrm{MgAlO}$ catalyst with $4 \%$ pre-adsorbed water than that $(131 \mathrm{~kJ} / \mathrm{mol})$ for the adsorption of acetone on clean $\mathrm{Ni} / \mathrm{MgAlO}$. The initial heats and coverages decreased for the $\mathrm{Ni} / \mathrm{MgAlO}$ catalyst with more pre-adsorbed water $(>10 \%)$. The initial heats and coverages decreased significantly for acetone adsorption on the $\mathrm{Ni} / \mathrm{MgAlO}$ catalyst with pre-adsorbed water coverages higher than $40 \%$. In this case, the presence of large numbers of pre-adsorbed water molecules could hinder access of acetone molecules to the Ni surface.

Figure 6 shows the microcalorimetric adsorption results for IPA at $308 \mathrm{~K}$ over the $\mathrm{Ni} / \mathrm{MgAlO}$ catalyst with different coverages of pre-adsorbed water. The initial heats were 91 and 152 $\mathrm{kJ} / \mathrm{mol}$ for the adsorption of IPA on MgAlO and Ni/MgAlO, respectively, indicating that IPA was adsorbed much more

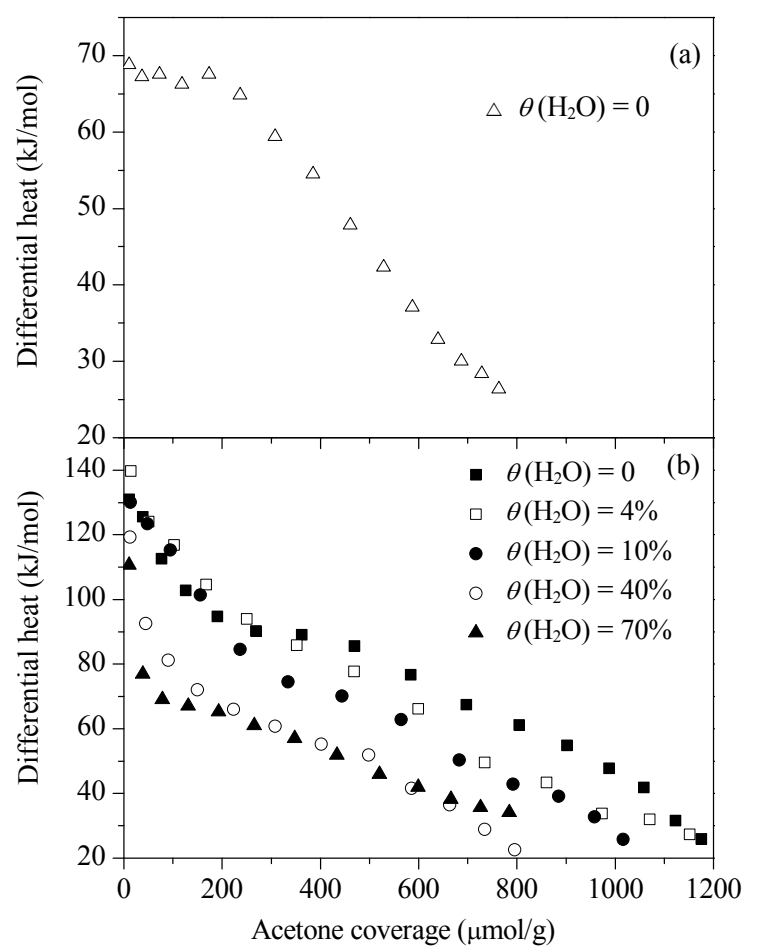

Fig. 5. Plots of differential heat versus coverage for adsorption of acetone at $308 \mathrm{~K}$ over MgAlO (a) and $\mathrm{Ni} / \mathrm{MgAlO}$ (b) with different coverages $(\theta)$ of pre-adsorbed water. The other details are the same as in Fig. 4.

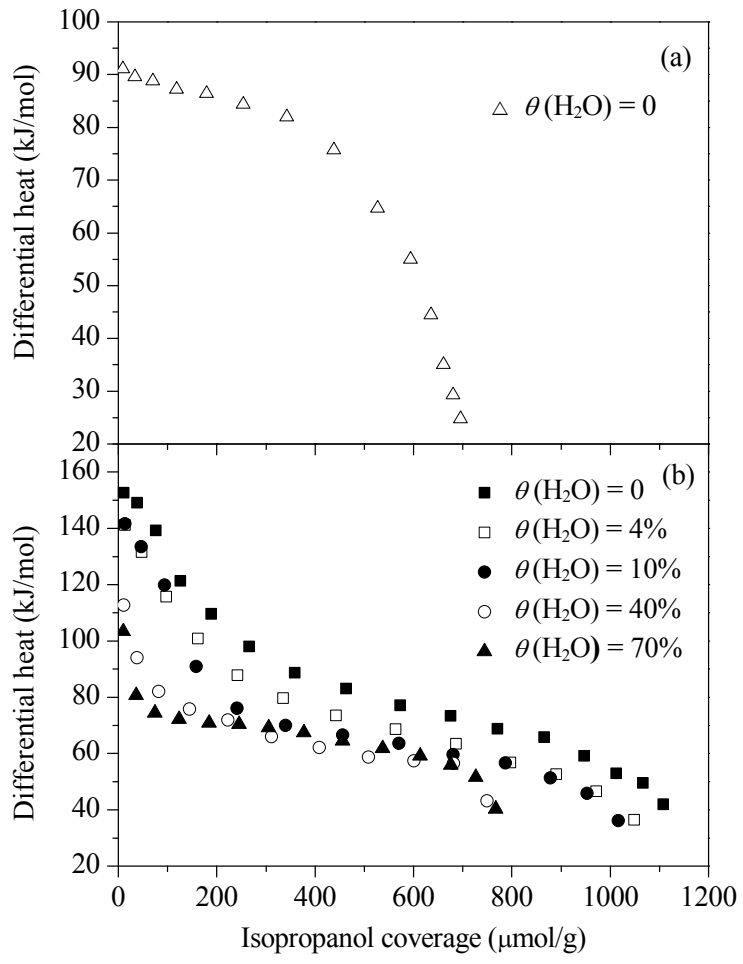

Fig. 6. Plots of differential heat versus coverage for adsorption of IPA at $308 \mathrm{~K}$ over MgAlO (a) and $\mathrm{Ni} / \mathrm{MgAlO}$ (b) with different coverages $(\theta)$ of pre-adsorbed water. Refer to Fig. 4 for other details.

strongly on metallic Ni than on the MgAlO support. In addition, these initial heats were significantly higher than those for acetone adsorption on the corresponding samples, indicating that IPA interacted more strongly than acetone with both the MgAlO support and the $\mathrm{Ni} / \mathrm{MgAlO}$ catalyst. The desorption of IPA from the catalyst surface might therefore play an important role in the hydrogenation of acetone. The initial heats and coverages for the adsorption of IPA on the $\mathrm{Ni} / \mathrm{MgAlO}$ catalyst decreased with increasing pre-adsorbed water coverage, especially for $40 \%$ and $70 \%$ coverages of pre-adsorbed water. Specifically, the initial heat was only $103 \mathrm{~kJ} / \mathrm{mol}$ for the adsorption of IPA on the $\mathrm{Ni} / \mathrm{MgAlO}$ catalyst with $70 \%$ coverage of pre-adsorbed water. The presence of water might therefore facilitate the desorption of IPA from the surface of the $\mathrm{Ni} / \mathrm{MgAlO}$ catalyst.

\subsection{Effects of water on surface structures of adsorbed acetone and IPA}

IR is a useful tool for understanding the surface structures of adsorbed acetone and IPA and the effects of water on surface structures. The adsorption states of acetone and IPA on metals and supports are complicated. Based on literature reports [15-26], some proposed surface species in the adsorption of acetone and IPA on the surfaces of $\mathrm{Ni} / \mathrm{MgAlO}$ and the MgAlO support are shown in Schemes 1 and 2, respectively.

Figure 7(1) shows the FT-IR spectrum of acetone adsorbed on MgAlO at room temperature. The main surface species formed are shown in Scheme 2(a). The band at $1701 \mathrm{~cm}^{-1}$ corresponds to the stretching vibrations of $\mathrm{C}=0$ in acetone mole- 
(a) $\eta^{1}(\mathrm{O})$-acetone

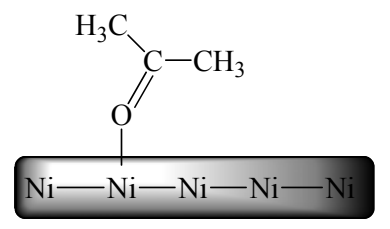

$1701 \mathrm{~cm}^{-1}(\nu \mathrm{C}=\mathrm{O})$

$1465 \mathrm{~cm}^{-1}\left(v_{\mathrm{as}} \mathrm{CH}_{3}\right)$

$1367 \mathrm{~cm}^{-1}\left(v_{\mathrm{s}} \mathrm{CH}_{3}\right)$

$1234 \mathrm{~cm}^{-1}(v \mathrm{C}-\mathrm{C}-\mathrm{C})$

(c) enol-isomer of acetone

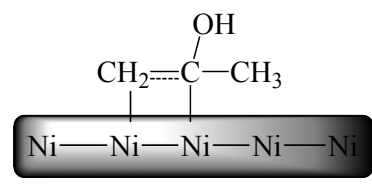

(e) isopropoxide

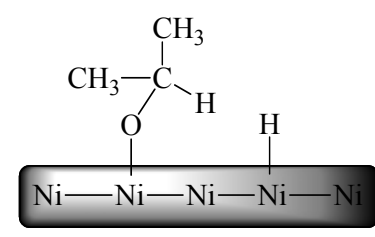

$1467 \mathrm{~cm}^{-1}\left(v_{\mathrm{as}} \mathrm{CH}_{3}\right)$
$1371 \mathrm{~cm}^{-1}\left(v_{\mathrm{s}} \mathrm{CH}_{3}\right)$
$1328 \mathrm{~cm}^{-1}(v \mathrm{CH})$
$1162 \mathrm{~cm}^{-1}(v \mathrm{C}-\mathrm{C} / \mathrm{C}-\mathrm{O})$
$1131 \mathrm{~cm}^{-1}$

Scheme 1. Schematic diagrams of proposed surface structures of adsorbed acetone and IPA on Ni surface, and their assigned IR frequencies.

cules adsorbed at Lewis acid sites. The bands at 1465 and 1367 $\mathrm{cm}^{-1}$ can be attributed to the symmetric and asymmetric bending vibrations of methyl groups $\left(-\mathrm{CH}_{3}\right)$. The band at 1234 $\mathrm{cm}^{-1}$ arises from the $\mathrm{C}-\mathrm{C}-\mathrm{C}$ stretching vibrations of acetone. These results are in agreement with previously reported data [20-22]. Two other bands were observed at 1643 and 1612 $\mathrm{cm}^{-1}$. Sanz et al. [22] proposed that the adsorption of acetone on MgO could lead to the formation of surface enolate species, shown by a band at $1640 \mathrm{~cm}^{-1}$ from the asymmetric stretching vibrations of $\mathrm{C}-\mathrm{C}-\mathrm{O}$ groups. Zaki et al. [21] reported that the aldol condensation of adsorbed surface acetone could be facilitated by surface acid-base sites on alumina or silica-alumina, leading to the formation of surface mesityl oxide species, with an absorption band at $1607 \mathrm{~cm}^{-1}$ from the $\mathrm{C}=\mathrm{C}$ stretching vibrations of mesityl oxide species coordinated to the surface Lewis acid sites. The FT-IR spectrum in Fig. 7(1) therefore indicates that both acetone enolate (Scheme 2(c)) and mesityl oxide (Scheme 2(d)) species were formed on the MgAlO surface.

For the FT-IR spectrum of acetone adsorbed on the $\mathrm{Ni} /$ MgAlO catalyst at room temperature (Fig. 7(2)), there are two configurations for the adsorption of acetone on metal surfaces (a) acetone

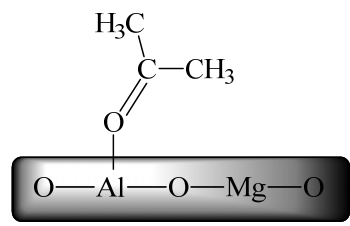

$1701 \mathrm{~cm}^{-1}(v \mathrm{C}=\mathrm{O})$

$1465 \mathrm{~cm}^{-1}\left(v_{\mathrm{as}} \mathrm{CH}_{3}\right)$

$1367 \mathrm{~cm}^{-1}\left(v_{\mathrm{s}} \mathrm{CH}_{3}\right)$

$1234 \mathrm{~cm}^{-1}\left(v \mathrm{C}^{-} \mathrm{C}^{-} \mathrm{C}\right)$

(c) enolate-isomer of acetone

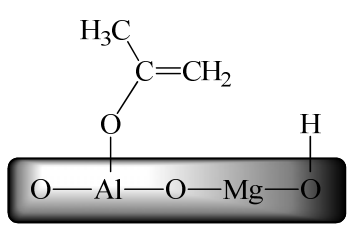

$1643 \mathrm{~cm}^{-1}\left(v_{\text {as }} \mathrm{C}^{-} \mathrm{C}^{-} \mathrm{O}\right)$

(e) isopropoxide

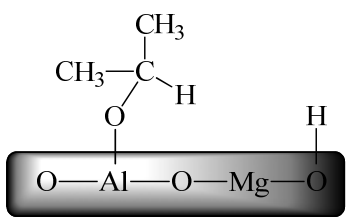

$$
\begin{aligned}
& 1467 \mathrm{~cm}^{-1}\left(v_{\mathrm{as}} \mathrm{CH}_{3}\right) \\
& 1371 \mathrm{~cm}^{-1}\left(v_{\mathrm{s}} \mathrm{CH}_{3}\right) \\
& 1328 \mathrm{~cm}^{-1}(v \mathrm{CH}) \\
& 1162 \mathrm{~cm}^{-1}(v \mathrm{C}-\mathrm{C} / \mathrm{C}-\mathrm{O}) \\
& 1131 \mathrm{~cm}^{-1}
\end{aligned}
$$

(d) mesityl oxide

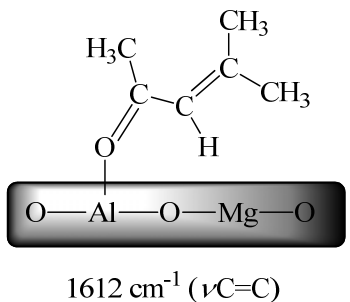

Scheme 2. Schematic diagrams of proposed surface structures of adsorbed acetone and IPA on surface of MgAlO support, and their assigned IR frequencies.

[15-17]. One is $\eta^{1}(0)$, which has an end-on adsorption geometry with bonding to the metal surface through the lone-pair

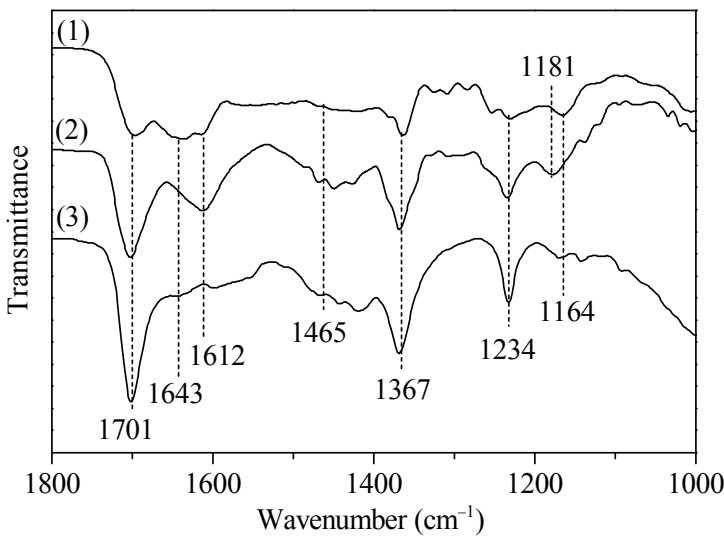

Fig. 7. FT-IR spectra of acetone adsorbed at $300 \mathrm{~K}$ on MgAlO (1), clean $\mathrm{Ni} / \mathrm{MgAlO}$ (2), and $\mathrm{Ni} / \mathrm{MgAlO}$ with pre-adsorbed water (3). Ni/MgAlO was reduced in $\mathrm{H}_{2}$ at $723 \mathrm{~K}$ for $2 \mathrm{~h}$ and evacuated at $723 \mathrm{~K}$ for $1 \mathrm{~h}$. The catalyst was then exposed to water vapor at $300 \mathrm{~K}$ for $15 \mathrm{~min}$ and evacuated at $300 \mathrm{~K}$ for $30 \mathrm{~min}$. The catalyst was then exposed to acetone vapor for $15 \mathrm{~min}$ and evacuated at $300 \mathrm{~K}$ for $30 \mathrm{~min}$ before the FTIR measurements. 
electrons of the oxygen atom (Scheme 1(a)), and the other is $\eta^{2}(\mathrm{C}, \mathrm{O})$, which has a side-on adsorption geometry bonded via the di- $\sigma$ mode involving both the oxygen and carbon atoms of the carbonyl group (Scheme 1(b)). In these configurations, the carbonyl group is almost perpendicular to the metal surface for the $\eta^{1}(0)$ mode and parallel to the surface for the $\eta^{2}(C, 0)$ mode. Because of the steric hindrance of methyl groups, the end-on $\eta^{1}(0)$ structure is generally considered to be more favorable than the parallel $\eta^{2}(C, 0)$ geometry [18]. The spectrum of acetone adsorbed on $\mathrm{Ni} / \mathrm{MgAlO}$ differs from that of acetone adsorbed on MgAlO. First, the intensity of the band at $1701 \mathrm{~cm}^{-1}$ is higher, indicating the presence of acetone with the $\eta^{1}(0)$ structure on $\mathrm{Ni}$, with a similar $\mathrm{C}=\mathrm{O}$ vibration frequency to that of acetone adsorbed on the MgAlO support. Secondly, the two bands at 1643 and $1612 \mathrm{~cm}^{-1}$ for acetone adsorbed on MgAlO merge into a broad and more intense band at $1612 \mathrm{~cm}^{-1}$ for acetone adsorbed on $\mathrm{Ni} / \mathrm{MgAlO}$, suggesting that more acetone enolate (Scheme 1(d)) or mesityl oxide species (Scheme 2(d)) were formed on $\mathrm{Ni} / \mathrm{MgAlO}$. The formation of enolate acetone species (Scheme 1(d)) on the surface of $\mathrm{Ni}(111)$ has been reported [19], with characteristic absorption bands at 1260, 1353 , and $1545 \mathrm{~cm}^{-1}$. Jeffery et al. [18] also observed acetone enolate species on $\operatorname{Pt}(111)$ surfaces and proposed that they were $\mu_{2}\left(\mathrm{C}_{1}, 0\right)$ enolate species, based on calculations and vibrational spectroscopic studies. Thirdly, a new band appears at $1181 \mathrm{~cm}^{-1}$ for acetone adsorbed on $\mathrm{Ni} / \mathrm{MgAlO}$, which is close to the predicted frequency $\left(1191 \mathrm{~cm}^{-1}\right)$ for the stretching vibration of $\mathrm{C}=0$ in the $\eta^{2}(\mathrm{C}, 0)$ acetone structure [19]. Acetone could therefore also be adsorbed on $\mathrm{Ni}$ via the $\eta^{2}(\mathrm{C}, \mathrm{O})$ mode (Scheme $1(\mathrm{~b})$ ). However, the band at $1701 \mathrm{~cm}^{-1}$ is much more intense than the one at $1181 \mathrm{~cm}^{-1}$, therefore the $\eta^{1}(0)$ structure was the main surface species for acetone adsorbed on $\mathrm{Ni}$.

For the IR spectrum of the adsorption of acetone on the $\mathrm{Ni}$ /MgAlO catalyst with pre-adsorbed water (Fig. 7(3)), the most noticeable change was the disappearance of the band at $1612 \mathrm{~cm}^{-1}$, indicating that the presence of water inhibited the surface reactions of acetone adsorbed on the surfaces of $\mathrm{Ni}$ and the support. It was reported that the aldol condensation of acetone adsorbed at Lewis acid-base sites led to the formation of diacetone alcohol, followed by dehydration to mesityl oxide [21]. These acid-base sites on the support might be covered by the pre-adsorbed water, and this would inhibit the isomerization and condensation reactions of adsorbed acetone. In addition, the presence of pre-adsorbed water would inhibit the formation of mesityl oxide because water is produced from the condensation reaction for the formation of mesityl oxide [38]. Moreover, the presence of pre-adsorbed water weakened the $\mathrm{Ni}-\mathrm{H}$ bonds, according to the microcalorimetric results for the adsorption of $\mathrm{H}_{2}$ reported above. The presence of pre-adsorbed water could therefore inhibit the dissociative adsorption of acetone for the formation of enol and enolate species (Scheme 1(c)-(d) and Scheme 2(b)-(c)).

Figure 8 shows the FT-IR spectra of IPA adsorbed on the MgAlO support and the $\mathrm{Ni} / \mathrm{MgAlO}$ catalyst at room temperature. On the MgAlO support, the bands appeared at 1467 and $1371 \mathrm{~cm}^{-1}$ are attributed to the asymmetric and symmetric bending vibrations of methyl groups, respectively. The band at

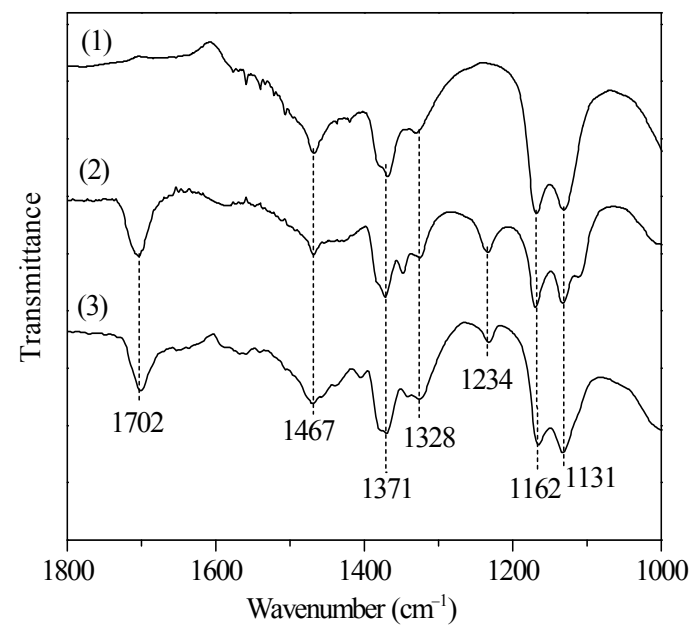

Fig. 8. FT-IR spectra of IPA adsorbed at $300 \mathrm{~K}$ on MgAlO (1), clean $\mathrm{Ni} / \mathrm{MgAlO}$ (2), and Ni/MgAlO with pre-adsorbed water (3). See Fig. 7 for other details.

$1328 \mathrm{~cm}^{-1}$ is caused by the bending vibrations of $\alpha-\mathrm{C}-\mathrm{H}$ bonds. The bands at 1162 and $1131 \mathrm{~cm}^{-1}$ are assigned to the coupled stretching vibrations of $\mathrm{C}-\mathrm{O} / \mathrm{C}-\mathrm{C}$ bonds. These bands are the characteristic absorption vibrations of surface isopropoxide species (Scheme 2(e)) [26,39,40]. No band was observed at $1280 \mathrm{~cm}^{-1}$ for the $\mathrm{O}-\mathrm{H}$ deformation vibration of IPA, indicating the absence of molecularly adsorbed IPA on MgAlO [39,40].

For the IR spectrum of IPA adsorbed on the clean Ni/MgAlO catalyst, two new bands appear, at 1702 and $1234 \mathrm{~cm}^{-1}$, compared with that on the support. These are assigned to the stretching vibrations of $\mathrm{C}=\mathrm{O}$ and $\mathrm{C}-\mathrm{C}-\mathrm{C}$ bonds, respectively, in adsorbed acetone (Scheme 1(a)), and indicate the dehydrogenation of adsorbed IPA to acetone on the Ni surface, in agreement with the reported results [23].

The IR spectrum of IPA adsorbed on $\mathrm{Ni} / \mathrm{MgAlO}$ with pre-adsorbed water is similar to that on clean $\mathrm{Ni} / \mathrm{MgAlO}$, except that the intensities of the bands at 1702 and $1234 \mathrm{~cm}^{-1}$ are lower, indicating that the presence of pre-adsorbed water inhibited IPA dehydrogenation to acetone. This might be another reason why the presence of a small amount of water accelerated the conversion of acetone to IPA. In contrast, the presence of large amounts of water significantly inhibited the adsorption of acetone and $\mathrm{H}_{2}$, leading to decreased activity for the hydrogenation of acetone to IPA.

\section{Conclusions}

The effects of water on the hydrogenation of acetone depended on the amount of water added. The addition of a small amount of water $(<5 \%)$ promoted the hydrogenation of acetone, whereas a large amount of water decreased the activity. Although the presence of water affected the textural and structural properties of the composite catalyst ( $\mathrm{Ni} / \mathrm{MgAlO}-\mathrm{MgAlO}$ ), the main phases in $\mathrm{Ni} / \mathrm{MgAlO}$ itself were not affected. The experimental results obtained by alternate feeding of pure acetone and acetone containing $40 \%$ water indicated that the effect of water on the hydrogenation of acetone was mainly the 
result of the effects of water on the surface reactions, rather than the effects on the textural and structural properties of the composite catalyst.

The heats of adsorption of acetone and IPA on the Ni/MgAlO catalyst were higher than those for adsorption on the MgAlO support, indicating that adsorbed acetone and IPA were more strongly bonded to Ni than to the support. In addition, IPA was more strongly bonded than acetone to $\mathrm{Ni}$, indicating that the desorption of IPA might be a more important factor in determining the activity in the hydrogenation of acetone. The microcalorimetric adsorption results showed that the presence of a small amount of water on the surface $(<4 \%$ coverage) promoted the adsorption of acetone (the heat of adsorption increased) on $\mathrm{Ni}$ and the desorption of IPA (the heat of adsorption decreased) from $\mathrm{Ni}$, leading to increased activity in the hydrogenation of acetone. However, the presence of a large amount of water inhibited the adsorptions of $\mathrm{H}_{2}$, acetone, and IPA, resulting in decreased activity in the hydrogenation of acetone.

FT-IR spectroscopy showed that the presence of pre-adsorbed water inhibited the dehydrogenation of adsorbed IPA to acetone on the surface of $\mathrm{Ni}$, which might be another important reason why the presence of some water promoted the activity in the hydrogenation of acetone. In addition, the pre-adsorbed water suppressed the formation of surface enolate and mesityl oxide species, which were the reaction intermediates in the formation of byproducts, therefore the presence of some water would be beneficial for the hydrogenation of acetone to IPA.

\section{References}

[1] Mäki-Arvela P, Hájek J, Salmi T, Yu Murzin D. Appl Catal A, 2005, 292: 1

[2] Singh U K, Vannice M A. Appl Catal A, 2001, 213: 1
[3] Mukherjee S, Vannice M A.J Catal, 2006, 243: 108

[4] Otto R, Brox J, Trippel S, Stei M, Best T, Wester R. Nat Chem, 2012, 4: 534

[5] Minakata S, Komatsu M. Chem Rev, 2009, 109: 711

[6] Chanda A, Fokin V V. Chem Rev, 2009, 109: 725

[7] Gómez-Quero S, Díaz E, Cárdenas-Lizana F, Keane M A. Chem Eng Sci, 2010, 65: 3786

[8] Butler R N, Coyne A G. Chem Rev, 2010, 110: 6302

[9] Cheng H Y, Meng X C, Yu Y C, Zhao F Y. Appl Catal A, 2013, 455: 8

[10] Masson J, Cividino P, Court J. Appl Catal A, 1997, 161: 191

[11] Akpa B S, D'Agostino C, Gladden L F, Hindle K, Manyar H, McGregor J, Li R, Neurock M, Sinha N, Stitt E H, Weber D, Zeitler J A, Rooney D W. J Catal, 2012, 289: 30

[12] Vaidya P D, Mahajani V V. Chem Eng Sci, 2005, 60: 1881

[13] Wan H J, Vitter A, Chaudhari R V, Subramaniam B. J Catal, 2014, 309: 174

[14] Li M S, Wang X D, Perret N, Keane M A. Catal Commun, 2014, 46: 187

[15] Houtman C, Barteau M A.J Phys Chem, 1991, 95: 3755

[16] Anton A B, Avery N R, Toby B H, Weinberg W H.J Am Chem Soc, 1986, 108: 684

[17] Vannice M A, Erley W, Ibach H. Surf Sci, 1991, 254: 1

[18] Jeffery E L, Mann R K, Hutchings G J, Taylor S H, Willock D J. Catal Today, 2005, 105: 85

[19] Sim W S, Li T C, Yang P X, Yeo B S. J Am Chem Soc, 2002, 124: 4970

[20] Hanson B E, Wieserman L F, Wagner G W, Kaufman R A. Langmuir, 1987, 3: 549

[21] Zaki M I, Hasan M A, Al-Sagheer F A, Pasupulety L. Langmuir, 2000, 16: 430

[22] Santz J F, Ovideo J, Marquez A, Odriozola J A, Montes M. Angew Chem Int Ed, 1999, 38: 506

[23] Shorthouse L J, Roberts A J, Raval R. Surf Sci, 2001, 480: 37

[24] Brown N F, Barteau M A. J Am Chem Soc, 1992, 114: 4258

[25] Davis J L, Barteau M A.J Mol Catal, 1992, 77: 109

[26] Martinez-Ramirez Z, Gonzalez-Calderon J A, Almendarez-Camarillo A, Fierro-Gonzalez J C. Surf Sci, 2012, 606: 1167

[27] Zhao J, Chen H, Tian X C, Zang H, Fu Y C, Shen J Y. J Catal, 2013,

\section{Graphical Abstract}

Chin. J. Catal., 2015, 36: 380-388 doi: 10.1016/S1872-2067(14)60240-0

\section{Effects of water on the hydrogenation of acetone over $\mathrm{Ni} / \mathrm{MgAlO}$ catalysts}

Hui Chen, Jie Zhao, Shaozhong Li, Jun Xu, Jianyi Shen*

Nanjing University
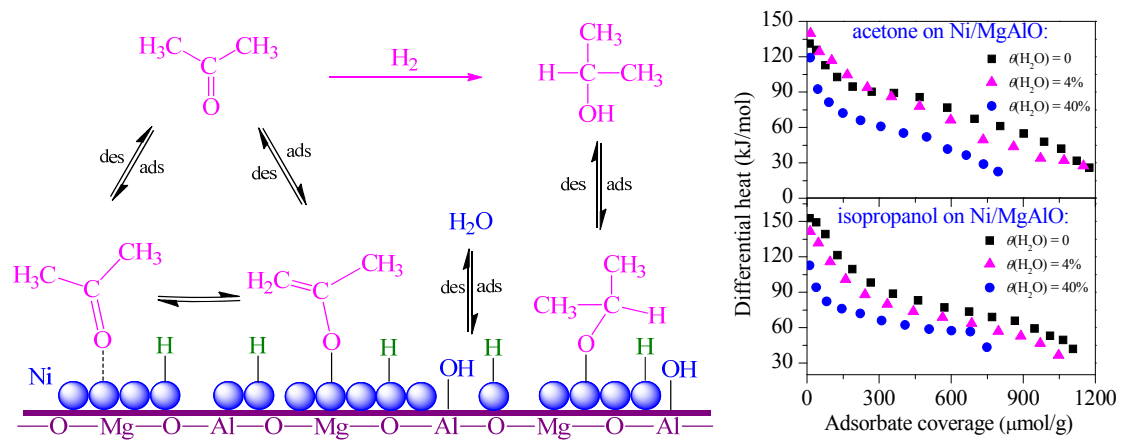

The presence of a small amount of pre-adsorbed water (4\%) enhanced the adsorption of acetone but inhibited the adsorption of isopropanol (IPA) on Ni, leading to increased activity in the hydrogenation of acetone to IPA. In contrast, the presence of a large amount of pre-adsorbed water significantly decreased the heats of adsorption of acetone and IPA, leading to decreased activity in the reaction. 
298: 161

[28] Zhao J, Chen H, Xu J, Shen J Y.J Phys Chem C, 2013, 117: 10573

[29] Chen H, Xue M W, Hu S H, Shen J Y. Chem Eng J, 2012, 181-182: 677

[30] Al-Dahhan M H, Larachi F, Dukukovic M P, Laurent A. Ind Eng Chem Res, 1997, 36: 3292

[31] Bizzi M, Basini L, Saracco G, Specchia V. Chem Eng J, 2002, $90: 97$

[32] Henderson M A. Surf Sci Rep, 2002, 46: 1

[33] Hodgson A, Haq S. Surf Sci Rep, 2009, 64: 381

[34] Ozensoy E, Szanyi J, Peden C H F. J Phys Chem B, 2005, 109: 3431
[35] Phatak A A, Delgass W N, Ribeiro F H, Schneider W F. J Phys Chem C, 2009, 113: 7269

[36] Shin H J, Jung J, Motobayashi K, Yanagisawa S, Morikawa Y, Kim Y, Kawai M. Nat Mater, 2010, 9: 442

[37] Koningsberger D C, Ramaker D E, Miller J T, de Graaf J, Mojet B L. Top Catal, 2001, 15: 35

[38] Rahman A. Bull Chem React Eng Catal, 2010, 5(2): 113

[39] Shimizu K I, Sugino K, Sawabe K, Satsuma A. Chem Eur J, 2009, 15: 2341

[40] Zaki M I, Hasan M A, Pasupulety L. Langmuir, 2001, 17: 4025

\section{水对 $\mathrm{Ni} / \mathrm{MgAlO}$ 催化丙酮加氢的影响}

陈 慧, 赵 杰, 李少中, 徐 军, 沈俭一

南京大学化学化工学院, 介观化学教育部重点实验室, 江苏南京210093

摘要: 研究了 $\mathrm{H}_{2} \mathrm{O}$ 对 $\mathrm{Ni} / \mathrm{MgAlO}$ 催化剂上丙酮加氢为异丙醇的催化反应的影响. 结果发现, 在丙酮中添加少量 $\mathrm{H}_{2} \mathrm{O}$ 可提高丙酮转化 率, 但超过 $5 \%$ 的 $\mathrm{H}_{2} \mathrm{O}$ 量则会显著降低催化剂活性. 吸附量热结果表明, 催化剂表面吸附少量 $\mathrm{H}_{2} \mathrm{O}$ 会明显降低异丙醇的吸附热, 但 对丙酮吸附热的影响较小, 这也许是反应体系中少量的 $\mathrm{H}_{2} \mathrm{O}$ 能促进丙酮加氢活性的原因之一. 当催化剂表面吸附较多 $\mathrm{H}_{2} \mathrm{O}$ 后, 丙 酮、异丙醇和 $\mathrm{H}_{2}$ 的吸附热都降低了, 因此反而抑制了丙酮的加氢反应. 此外, 红外光谱结果表明, 预吸附水抑制了催化剂表面异丙 醇脱氢生成丙酮, 并抑制吸附的丙酮在表面生成烯醇盐或异丙叉丙酮等物种, 这也许是少量水能促进丙酮加氢生成异丙醇的另一 个重要原因.

关键词: 镍; 负载型催化剂; 丙酮加氢; 水的影响; 吸附量热; 红外光谱

收稿日期: 2014-08-15. 接受日期: 2014-09-29. 出版日期: 2015-03-20.

*通讯联系人. 电话/传真: (025)83594305; 电子信箱: jyshen@nju.edu.cn

基金来源：国家自然科学基金(21273105); 江苏省自然科学基金青年基金(BK20140596); 国家高技术研究发展计划(863计划, 2013AA031703).

本文的英文电子版由Elsevier出版社在ScienceDirect上出版(http://www.sciencedirect.com/science/journal/18722067). 